\title{
When disciplinary convergence becomes a must!
}

I take the occasion of the publication of the last special issue of FRUITS on "Fruit production under bydric and saline constraints" to treat a subject dear to my heart. In the editorial of this special issue, Dr. Raphael Morillon stresses the importance of the subject as a way to respond to the climate change, even more problematic as it addresses perennial crops, which is the case of a lot of fruit species.

To address this concern, one solution is to use more varieties and species tolerant to drought and salinity, and it is one that is widely advocated by the whole sphere of plant breeding as evidenced by recent communications to conferences on the subject.

When addressing the sphere of specialists in water stress, the solutions proposed fall over the water control in the plant, soil and air by using techniques of drainage and irrigation, but also windbreaks, mulching or tillage, shade or other agronomic practices, which are also the subject of communications to numerous seminars on the subject.

But there are few places for interaction between the two spheres, while the best solutions to the current and expected climate change, as well as to the increasing tensions between the various water usages, are probably at the intersection of both spheres: an agriculture in one place based on the species that are best adapted to the water stress at that place, taking into account the possibilities of optimizing their production through better management of available water.

A disciplinary convergence is therefore needed between the breeders and the water management specialists to better address the increasingly strong challenges related to this precious resource that is water.

Dr. Jacky Ganry Scientific Director of Fruits 


\section{Quand une convergence disciplinaire s'impose !}

Je voudrais saisir l'occasion de la publication du dernier numéro hors-série de FRUITS sur " La production fruitière sous contraintes hydrique et saline " pour traiter d'un sujet qui me tient particulièrement à cour. Dans l'éditorial de ce numéro spécial, Raphaël Morillon souligne l'importance du sujet face à l'évolution du climat, d'autant plus problématique que l'on s'adresse à des productions pérennes, ce qui est le cas de nombreuses espèces fruitières.

Pour faire face à cette situation préoccupante, une solution proposée est d'avoir recours à des variétés et espèces plus résistantes à la sécheresse et à la salinité, et c'est celle qui est largement préconisée par toute la sphère de l'amélioration des plantes comme en témoignent les communications aux récents colloques sur le sujet.

Lorsque l'on s'adresse à la sphère des spécialistes du stress hydrique, les solutions proposées relèvent surtout de la maitrise de l'eau dans la plante, dans le sol et dans l'atmosphère en ayant recours à des techniques de drainage et d'irrigation, mais aussi de brisevent, de couverture ou de travail du sol, d'ombrage ou autres pratiques de type agronomique, qui font également l'objet de communications aux nombreux colloques sur le sujet.

Mais rares sont les lieux d'interaction entre les deux sphères, alors que les solutions les plus adaptées aux changements climatiques en cours et attendus, ainsi qu'aux tensions de plus en plus fortes entre les divers usages de l'eau, se situent probablement à l'intersection des deux sphères : baser l'agriculture d'un lieu sur les espèces les mieux adaptées aux contraintes hydriques de ce lieu, tout en tenant compte des possibilités d'optimiser leur production grâce à une meilleure gestion de l'eau disponible.

Une convergence disciplinaire s'impose donc entre les spécialistes de l'amélioration des plantes et ceux de la gestion de l'eau pour mieux aborder les défis de plus en plus forts liés à cette précieuse ressource qu'est l'eau. 